\title{
CUNEGEO
}

International Journal of Environment and Geoinformatics (IJEGEO) is an international, multidisciplinary, peer reviewed, open access journal.

\section{The Development of Environmental Human Rights}

\section{Emrah AKYÜZ}

\section{Chief in Editor}

Prof. Dr. Cem Gazioğlu

Co-Editors

Prof. Dr. Dursun Zafer Şeker, Prof. Dr. Şinasi Kaya,

Prof. Dr. Ayşegül Tanık and Assist. Prof. Dr. Volkan Demir

Editorial Committee (June 2021)

Assoc. Prof. Dr. Abdullah Aksu (TR), Assit. Prof. Dr. Uğur Algancı (TR), Prof. Dr. Bedri Alpar (TR), Assoc. Prof. Dr. Aslı Aslan (US), Prof. Dr. Levent Bat (TR), Prof. Dr. Paul Bates (UK), İrşad Bayırhan (TR), Prof. Dr. Bülent Bayram (TR), Prof. Dr. Luis M. Botana (ES), Prof. Dr. Nuray Çağlar (TR), Prof. Dr. Sukanta Dash (IN), Dr. Soofia T. Elias (UK), Prof. Dr. A. Evren Erginal (TR), Assoc. Prof. Dr. Cüneyt Erenoğlu (TR), Dr. Dieter Fritsch (DE), Prof. Dr. Çiğdem Göksel (TR), Prof.Dr. Lena Halounova (CZ), Prof. Dr. Manik Kalubarme (IN), Dr. Hakan Kaya (TR), Assist. Prof. Dr. Serkan Kükrer (TR), Assoc. Prof. Dr. Maged Marghany (MY), Prof. Dr. Michael Meadows (ZA), Prof. Dr. Nebiye Musaoğlu (TR), Prof. Dr. Masafumi Nakagawa (JP), Prof. Dr. Hasan Özdemir (TR), Prof. Dr. Chryssy Potsiou (GR), Prof. Dr. Erol Sarı (TR), Prof. Dr. Maria Paradiso (IT), Prof. Dr. Petros Patias (GR), Prof. Dr. Elif Sertel (TR), Prof. Dr. Nüket Sivri (TR), Prof. Dr. Füsun Balık Şanlı (TR), Prof. Dr. Uğur Şanlı (TR), Duygu Ülker (TR), Prof. Dr. Seyfettin Taş (TR), Assoc. Prof. Dr. Ömer Suat Taşkın (TR), Assist. Prof. Dr. Tuba Ünsal (TR), Dr. Manousos Valyrakis (UK), Dr. İnese Varna (LV), Dr. Petra Visser (NL), Prof. Dr. Selma Ünlü (TR), Assoc. Prof. Dr. Oral Yağcı (TR), Prof. Dr. Murat Yakar (TR), Assoc. Prof. Dr. İ. Noyan Yılmaz (AU); Assit. Prof. Dr. Sibel Zeki (TR) 
Review Article

\title{
The Development of Environmental Human Rights
}

\author{
Emrah Akyüz iD \\ University of Bingöl, Bingöl Vocational School of Social Sciences, Deperment of Management and Organization, Bingöl/TR
}

* E-mail: emrahylsy@ hotmail.com

Received 12 Dec 2020 Accepted 24 Jan 2021

How to cite: Akyüz (2021). The Development of Environmental Human Rights, International Journal of Environment and Geoinformatics (IJEGEO), 8(2): 218-225. doi. 10.30897/ijegeo.839725

\begin{abstract}
Human rights and the environment are linked with each other in two ways. Firstly, the environment is seen as pre-condition of the realization of human rights. Because human beings are dependent on the environment. We all meet our basic needs including air, water and food from nature. Individuals cannot exist without the mother earth. For this reason, human rights may not be enjoyed at the absence of a clean environment. Secondly, human rights can be an effective way to achieve environmental safety. These two linkages are united under the umbrella of environmental human rights. Environmental human rights are the rights of people to protect the environment for the sake of human beings. There have been numerous studies investigating the scope and types of environmental human rights. However, how the linkage between human rights and the environment has been evolved has not been discussed sufficiently so far. Accordingly, this paper aims to explore how environmental human rights have been developed over history. This research finds that environmental human rights have been developed by international environmental law more than international human rights law.
\end{abstract}

Keywords: Environmental Human Rights, Human Rights, Right to Clean Environment, Procedural Rights.

\section{Introduction}

Environmental human rights are based on the relationship between the environment and human rights. Environmental human rights can be perceived in two distinct ways. Firstly, the environment has been regarded as pre-condition of basic human rights including the right to life and health since the 1972 Stockholm Declaration. This assumption derives from the fact that nature provides food, water and air that all human beings need for survival. People cannot exist without the environment because we all meet our basic needs from nature. For this reason, people are dependent on the environment. In other words, the environment appears the most important element of human lives. This results in the fact that people cannot enjoy or realize human rights at the absence of safe environment because the quality of nature affects people's lives. Due to the importance of nature on people's lives, environment is considered essential for the enjoyment of human rights.

The second aspect of the connection between the environment and human rights is that human rights can be an effective way to address environmental issues and to influence environmental policy. There are four types of human rights which can be used by the concerned people in environmental matters. The first one is the right to safe environment which refers that people have a right to live in a clean and safe environment. The second one is the reinterpretation of existing human rights which means that internationally recognized human rights already require safe environment. The third one is civil and political rights including freedom of expression, right to association and right to assembly. The last one is procedural rights including right to access to information, right to participation in decision making process and right to access to justice. All these human rights can be used effectively by individuals to affect environmental policy and address environmental problems that people face.

The connection between the environment and human rights has been discussed by previous studies sufficiently so far. There have been, however, a few researches investigating how environmental human rights have been evolved over history. The main purpose of this paper is to argue the development of environmental human rights. This paper consists of three main parts. It firstly argues what dynamics have caused the emergence of environmental human rights. It then argues how international and regional environmental law has contributed to the development of environmental human rights. Lastly, it explores how regional and international human rights law has contributed to the development of environmental human rights.

\section{The Emergence of Environmental Awareness}

Environmental degradation is an age-old issue. It has been occurring throughout human history, from the earliest settlements to modern society, as reflected in recent headlines (Karabıçak and Armağan, 2004: Gazioğlu, 2018). Similarly, concern for environmental matters is not a new phenomenon. Evidence of environmental concern, in particular concern related to air pollution, can be found in different periods in history. 
For instance, after Londoners complained about the smoke, Edward I, the fifth Plantagenet king of England, decided to ban the burning of sea-coal by proclamation in London in the 13th century (Urbinato, 1994). A closer look at the data indicates that laws which counter environmental problems are as old as public concern about an unsafe environment. However, it does not seem quite right to date the origins of environmental rights to Edward I's decision to curb the smoke in London because of two main reasons: firstly, this decision was not taken up by the international community and thus remained local and was not based on any specific environmental right; secondly, and more importantly, the key purpose here was to protect the public, not the environment. Environmental rights, as they exist today, make explicit reference to the protection of the environment itself.

It may be useful to clarify why environmental rights are relatively new when environmental issues and public concerns date back to earlier times. On logical grounds, it seems fair to link the emergence of environmental issues with environmental rights, as environmental rights emerged as a response to increasing environmental contamination and its impact on human lives after the 1950s. There may be many different answers to this question, but one stands out; namely, that environmental issues became a global concern in the second half of the 20th Century (Anton and Shelton, 2011) when the world started to witness a rapidly growing population (the world population was 1 billion in 1800 and increased to 2,5 billion in the 1950s) (Our World in Data, 2019), the use of technology increased and the patterns of production and consumption started changing (Karabıçak and Armağan, 2004). This all triggered environmental degradation. The second half of the 20th Century was when the international voice on environmental protection was first strongly raised and this automatically triggered the development of environmentalism at an international scale.

There is consensus in the literature that the $1960 \mathrm{~s}$ marked the emergence of modern environmental thinking in the political, social and academic agenda and this greatly impacted the public's consciousness and marked the beginning of modern environmentalism (Karabıçak and Armağan, 2004; De Steiguer, 2006; Ülker et al., 2018-2020). Indeed, a number of significant developments happened in the 1960s and 1970s, which led to the emergence of a strong public awareness on environmental matters and intensified the call for countries to cooperate to protect and conserve the earth's ecosystem, that is its land, air, water, animals, plants and entire habitats such as rainforests, deserts and oceans, at an international level (Karabıçak and Armağan, 2004). Environmentalism began as a movement after the 1950s (Hays, 1981). Also, at this time philosophers joined the debate and a new branch of ethics was born: environmental ethics. In the 1970s, the first international academic journal in this field (the US-based Journal of Environmental Ethics) emerged and environmental history was born as a new discipline in the United States. In addition, this era saw the publication of Rachel
Carson's Silent Spring, which contributed to development of environmental movement, in 1962 (De Steiguer, 2006); the publication of the Report for the Club of Rome, Limits to Growth, which focused considerable public attention on environmental matters, at the beginning of the 1970s (Colombo, 2001); and, the foundation of the Greenpeace movement in 1969 (Eden, 2004), which brought environmental issues to the public's attention and influenced both the private and the public sectors.

These developments were not surprising as the public was not concerned only because of the contamination of nature, but also because of the contamination's negative impact on human well-being. The 'Great Smog' of 1952 (also known as the 'Big Smoke') is, for instance, accepted as being one of the worst air-pollution events in the history of the UK, resulting in 4000 deaths (Chauhan and Johnston, 2003). The 1952 incident, along with similar environmental issues which had an impact on public health, resulted in environmental protection being viewed during the 1960 s as being a matter of public concern (Anton and Shelton, 2011). It would be more appropriate to define the 1950s and the aftermath of the Great Smog as a period of the emergence of an "environmental crisis" that threatened human beings in a deadly manner. Not surprisingly, this alarming situation led to the concept that a safe environment is necessary for the safeguarding of human well-being on a global scale. It seems reasonable to state that the inclusion of an environmental dimension in the human rights debate during the 1970s was in response to an urgent need to protect human well-being from being impacted by the effects of increasing environmental degradation, which started seriously to threaten people at an international level.

\section{International Environmental Law and Environmental Human Rights}

The conference on the Human Environment, held in Stockholm in 1972, represented major milestones in the evolution of environmental rights (Cramer, 2009: Gellers, 2012). The 1972 Stockholm Declaration on the Human Environment is the first authoritative instrument, which recognizes the close relationship between environmental protection and human rights at an international level (Gellers, 2012; Peters, 2018). The Stockholm Declaration can be considered a turning point in environmental human rights as the conference proposed a human rights approach to environmental protection and recognized its impact on human rights (Cramer, 2009; UN, 1972; Wisadha and Widyaningsih, 2018; Jankuv, 2019; Ahmetoğlu, and Tanık, 2020). The Declaration is significant in many ways, not least because it established the link between human rights and environmental protection (Olawuyi, 2014). It proclaims that "Both aspects of man's environment, the natural and the man-made, are essential to his well-being and to the enjoyment of basic human rights the right to life itself" (UN, 1972). It clearly defines that the exercise of basic human rights inevitably requires environmental protection; this means that basic environmental standards 
are regarded as a pre-condition to the enjoyment of human rights (Olawuyi, 2014). This was a novel idea and it was the first time that the link between the environment and human rights was recognised at an international level.

Controversy around the Declaration was not lacking. It was open to criticism from a number of angles. The main criticism directed at it was because the principles are hard to implement in practical terms within environmental policy. Much of the current debate revolves around such principles failing to go beyond advice or recognition and therefore remaining insufficient and ineffective due to weak institutional and compliance mechanisms, particularly as these rights are not legally enforceable (Sands, 1993; Anton and Shelton, 2011). This criticism comes across as unilateral, biased and pointless given that the main purpose of the Stockholm Declaration was to inspire and guide human beings in the preservation and enhancement of the human environment, not to establish enforcement mechanisms at an international level. The Stockholm Declaration is an advisory statement of purpose, a socalled "soft" law, which does not have any legally binding force (Wirth, 1995). Secondly, and maybe more importantly, there is a lack of clarity in the definition of the relationship between the environment and human beings. The principles enshrined in the Declaration are confusing. It leaves a number of controversial questions unanswered, the main one being "Why should we protect the environment?" Is it only for human being's benefit, or is it also for nature's own value? If taken from an ethical perspective, it appears reasonable to say that the Declaration principally concentrates on human needs, and neglects the non-human world and other aspects of nature; which means that the value of the environment is determined by the rationality of human needs. Thirdly, this Declaration fails to identify a separate solidarity right, i.e. the right to a healthy environment. Given that the environment is essential for human well-being and the enjoyment of basic rights, why did the Declaration not recognize a substantive right to a healthy environment? Lastly, it can be argued that defining the environment as a pre-condition of realization of human rights is inherently risky because the lack of these alleged pre-conditions (a safe environment) might be used to deny human rights. This argument seems to hold water because if a safe environment is essential for the enjoyment of human rights and if this does not exist (one of the main concerns of the modern world being heavy environmental contamination such as air pollution), it can arguably be claimed that human rights do not exist because a safe environment does not exist. This is another unclear and confusing point that the Declaration fails to clarify. In sum, therefore, the recognition of the link between the environment and human beings' well-being by the Declaration was a significant development, but proved to be insufficient in terms of providing a comprehensive map and developing an elaborate framework to reveal the ways in which the two interact.
The 1992 Rio Declaration, which was approved by 178 countries as an essential feature of environmental governance, is another important document that builds upon the basic ideas concerning the attitudes of individuals and nations towards the environment (UN, 2011). It reaffirmed the 1972 Stockholm Declaration and sought to build on it (UN, 1992). Arguably, it can be said that the 1992 Rio Declaration contributes to the development of environmental rights more than the 1972 Stockholm Declaration does as the Rio Declaration does not only focus on the recognition of environmental rights but also on the responsibilities of human beings to achieve a safe environment. While the Stockholm Declaration puts forward the narrow perspective that the environment is just a tool for the enjoyment of human rights (UN, 1972), in the Rio Declaration procedural human rights are, seen as an effective tool through which to address environmental matters (UN, 1992). This is an important turning point which saw environmental rights evolving from being a pre-condition for the enjoyment of human rights to the notion of the protection of the environment for its own sake. Another main difference between the two declarations is that, while the 1972 Stockholm Declaration does not go beyond recognizing the link between the environment and human rights, the Rio Declaration defines the right to oppose environmental contamination and emphasizes the responsibility of human beings to safeguard the common environment. For this reason, Porras (1992) describes the Rio Declaration as an unprecedented and ambitions event. This emphasis is understandable because Principle 10 of the Declaration, in particular, is unique in that it defines and fosters procedural environmental rights which have been commonly conceived as being more transparent, inclusive, and accountable in the decisionmaking progress concerning matters affecting the environment that people are dependent upon (Banisar, 2011; Peters, 2018). Principle 10 states that:

"Environmental issues are best handled with
the participation of all concerned citizens, at
the relevant level. At the national level, each
individual shall have appropriate access to
information concerning the environment that is
held by public authorities, including
information on hazardous materials and
activities in their communities, and the
opportunity to participate in decision-making
processes. States shall facilitate and
encourage public awareness and participation
by making information widely available.
Effective access to judicial and administrative
proceedings, including redress and remedy,
shall be provided" (UN, 1992).

This principle makes positive contributions to the development of environmental rights in two ways. Firstly, a closer look at the principle indicates that the Declaration constructs the relationship between the environment and human rights in the field of procedural rights including right to public participation in decision making process, right to access to information and right to access to justice (Olmos Giupponi, 2019). It is the first 
time that procedural environmental rights are recognised by a declaration at an international level and this inspired countries to adopt the principle in their domestic environmental policy. Not surprisingly, procedural environmental rights have been inserted in the legislation of an overwhelming number of countries, including countries in Africa, Asia and America (Banisar, 2011). Secondly, the Declaration can be considered a very useful guide in categorising procedural environmental rights including the right to information, a right to participate, and a right to access justice. Principle 10 sets out the fundamental elements for good environmental governance (UN, 1992), which is critical for the achievement of environmental sustainability.

It would be subjective to mention only the positive sides of the Rio Declaration for environmental rights as this Declaration drew criticisms which were similar to the ones levelled at the Stockholm Declaration. The main criticism seems to be that it is not yet obvious how seriously state parties relate these principles to their national and local environmental policies. The main rationale behind this criticism stems from the fact that the principles set out in the Declaration are not legally binding. Indeed, the lack of legally enforceable environmental rights makes the Rio Declaration weak and ineffective when it comes to forcing states to implement environmental policy in accordance with its objectives. In terms of the establishment of an enforcement mechanism at an international level, the Rio Conference may be described as disappointing as it did not make a significant impact on the development of environmental rights since the Stockholm Declaration. Another criticism can be the fact that the Declaration does not mention a distinct right to a healthy environment. On logical grounds, there is no compelling reason to argue why the Rio Declaration did not recognise a distinct right to a healthy environment as it already provided environmental rights by recognising procedural rights. Arguably if procedural rights are an effective way to protect the environment, on logical grounds it seems reasonable to say that there is no need for a distinct right to a healthy environment and this makes discussion useless. Therefore, the Declaration is a useful reference for policy-makers, legislators and officials at all levels of government, but remains ineffective due to the lack of inherent enforcement mechanisms.

The Aarhus Convention, which was adopted in 1998 and entered into force in 2001 (Koester, 2017; Mason, 2010; Baber and Bartlett, 2020; Berny, 2018), takes procedural environmental rights a step further and puts Principle 10 of the Rio Declaration on the Environment and Development into practice. It can be accepted as the world's foremost international instrument that links environmental and human rights and is regarded as a landmark in environmental democracy (Wates, 2005). It is the first multilateral treaty to specifically denote a human right to government information about environmental policy and decisions related to the environment (Cramer, 2009). How Kofi Annan, who was the seventh Secretary-General of the United Nations, describes the Aarhus Convention summarises its importance for environmental rights. He states:

"The Aarhus Convention is the most ambitious
venture in environmental democracy
undertaken under the auspices of the United
Nations. Its adoption was a remarkable step
forward in the development of international
law. ... The firm commitment to [the
Convention's] principles of ... States in
Eastern Europe and Central Asia ... clearly
demonstrates that environmental rights are not
a luxury reserved for rich countries... We must
use next year's World Summit on Sustainable
Development to strengthen our commitment to
environmental rights - not only in Europe but
throughout the world." (UNECE, 2011).

The strength of this Convention lies in its legally binding obligations on public authorities (Samvel, 2020; Kravchenko, 2007; Samvel, 2020). It is the first international legally binding instrument which recognises citizens' procedural rights in environmental matters (Kravchenko, 2007). It not only recognises environmental rights as a key characteristic of good governance but also guarantees the rights of access to information, public participation and access to justice for effective environmental governance (Samvel, 2020; Toth, 2010). The Convention has 47 Parties (46 states and the European Union) which means that the Convention' scope of application is regional (Peters, 2018; Krämer, 2018). Each Party is obliged to guarantee the rights set out in the Convention (UNECE, 2005). What is unique about the Aarhus Convention is its Compliance Committee (Kravchenko, 2007; Koester, 2007). Article 15 of the Convention requires the Parties to set up arrangements of a non-confrontational, nonjudicial and consultative nature to review compliance with the Convention for the effective enjoyment of the Aarhus Convention rights by the public throughout the EU (Samvel, 2020; Samvel, 2020). It states:

\begin{abstract}
"The Meeting of the Parties shall establish, on a consensus basis, optional arrangements of a non-confrontational, non-judicial and consultative nature for reviewing compliance with the provisions of this Convention. These arrangements shall allow for appropriate public involvement and may include the option of considering communications from members of the public on matters related to this Convention"(European Commission, 1998).
\end{abstract}

In order to fulfill Article 15 of the Convention, the Aarhus Convention Compliance Committee was established in 2002 (Koester, 2007; Morgera, 2005). It is mandated to discuss and decide on possible violations of the Convention. The Aarhus Convention compliance mechanism can be triggered in four main ways:

“(1) a Party may make a submission about compliance by another Party; 
(2) a Party may make a submission concerning its own compliance;

(3) the secretariat may make a referral to the Committee; and

(4) members of the public may make communications concerning a Party's compliance with the convention." (UNECE, n.d)

This is one of the noticeable characteristics of the Aarhus Convention.

It would, however, be amiss to limit the importance of the Aarhus Convention to only the recognition and protection of procedural environmental rights. Procedural environmental rights are not only important in their own right but are also essential to the successful realisation of substantive environmental rights. There are legally enforceable human rights such as the right to expression, which is well protected and guaranteed by national and international law- Article 19 of The Universal Declaration of Human Rights which states that

\section{"Everyone has the right to freedom of opinion} and expression ..." (UN, n.d).

Right to expression may enable concerned groups to voice their objection to environmental protection and make effective claims for environmental protection. When a sufficient number of concerned people raise their voices about environmental matters governments can be forced to implement more sustainable environmental policies to meet their citizen's needs. However, the right to expression may remain ineffective if citizens do not have access to relevant environmental information. If the citizens are not well-informed, are illinformed or lack sufficient information, it is unreasonable to expect them to express opinions and concerns which may be relevant to environmental decisions. The effective implementation of all the procedural rights can be seen as a fundamental condition for realizing the substantive right to an adequate level of environmental quality. The Aarhus Convention, therefore, makes a valuable contribution to the realisation of environmental rights, as it protects procedural environmental rights, which are also a highly valuable tool to empower particularly vulnerable and excluded people to invoke their substantive rights.

\section{International Human Rights Law and Environmental Human Rights}

While procedural environmental rights have made major progress over the last few decades, international human rights instruments still do not include a distinct right to a healthy environment (Pathak, 2014). At the international level, there is no explicit right to environmental quality recognised by either the Universal Declaration on Human Rights 1948 (UDHR) or the International Covenant on Civil and Political Rights, which are two major human rights documents (Glazebrook, 2009; Pathak, 2014). However, although a legally enforceable human right to a healthy environment has still not been achieved through international supervisory mechanisms which are relatively strong since the UN first expressly linked human rights to the environment in the 1972 Stockholm Declaration, the notion has evolved in a way that has had a noticeable impact on international human rights and environmental policy, as can be seen in the Draft Declaration of Human Rights and the Environment (DDHRE), developed by the United Nations in 1994, which clearly recognised a substantive right to a healthy environment (University of Minnesota Human Rights Library, 1994).

DDHRE is guided by the principles of the 1972 Stockholm and the 1992 Rio Declarations. While the Stockholm Declaration implied the close link between the two, DDHRE clearly defines environmental rights in broadly qualitative terms and recognises a distinct right to a healthy environment which is seen as essential to the enjoyment of all human rights. The second principle states: "All persons have the right to a secure, healthy and ecologically sound environment. This right and other human rights, including civil, cultural, economic, political and social rights, are universal, interdependent and indivisible." (University of Minnesota Human Rights Library, 1994). There is no doubt that recognition of the right to a safe environment as a human right by the United Nations is a key milestone, but this recognition remains ineffective as long as it remains non-enforceable by an international court. It is not clear how seriously the UN takes the safeguarding of recognised environmental rights. What is needed for the right to a healthy environment to be enforceable is evolution from recognition by soft laws (such as the 1972 Stockholm Declaration) to protection by hard law which involves legal norms that are legally binding. This has still not been achieved by the international community.

There are 900 international legal instruments which deal with international human rights issues (Olawuyi, 2014). However, the international human rights and environmental law frameworks have not yet been integrated in spite of the interrelated and interconnected relations between the two fields as recognized by the 1972 Stockholm Declaration. Environmental degradation and human rights abuse are the two main concerns of the modern world but there is no common international law protecting both the environment and human rights. They remain incomplete until a common framework which links international human rights with environmental rights is created. Thus, it does not seem plausible to talk about the maturity of environmental rights when the right to a healthy environment is not enforceable through any enforcement mechanism at the international level.

There have been a number of regional hard laws passed which recognise the right to a healthy environment including the African Charter on Human and Peoples' Rights and the Additional Protocol to the American Convention on Human Rights (Pathak, 2014: p. 20). One of the most important is the African Charter on Human and Peoples' Rights, which is a human rights instrument which intends to promote and protect human rights in 
Africa (Umozurike, 1983). It was adopted in 1981 by the Organisation of African Unity and it has notable unique characteristics as it is one of the precious few hard laws that guarantee a distinct right to a healthy environment at a regional level (Humphreys, 2015; Atapattu, 2002). More so than other comparable human rights laws, it clearly defines, recognises and protects a substantive right to a healthy environment. Article 24 of this document states that, "All peoples shall have the right to a general satisfactory environment favourable to their development" (ACHPR, 1981). This is a very positive development where the environment is not only seen as a pre-condition for the enjoyment of human rights but is also accepted as one of the fundamental human rights. However, the unique feature of the African Charter is that it goes beyond the recognition of a right to a healthy environment and imposes obligations on the individuals towards the State and the community (ACHPR, 1981; Gittleman, 1981). Article 1 states that:

"The Member States of the Organization of
African Unity parties to the present Charter
shall recognize the rights, duties and freedoms
enshrined in this Charter and shall undertake
to adopt legislative or other measures to give
effect to them" (ACHPR, 1981).

Recognition of environmental rights is not new but the protection of environmental rights through an enforcement mechanism at a regional level is unique. Article 24, however, can be criticised as being too anthropocentric as it conceives the environment in a narrow way, seeing nature as a tool which can be used to satisfy human needs, ignoring the value of nature in itself. This is not surprising as all other human rights instruments put human beings at the centre of the planet and consider them to be the most significant species. Additionally, environmental problems cannot always be confined within the boundaries of a single country or region; they can sometimes cross boundaries and spread to a global scale (Karabiçak and Armağan, 2004; Cramer, 2009). For example, the Fukushima accident, which happened in Asia, also affected Greece in Europe (Kritidis et al., 2012). If an environmental contamination issue crosses boundaries a regional document may not be sufficient to address it. However, the African Charter remains a very positive contribution to the development of environmental rights as it guarantees a distinct right to a safe environment in Africa.

\section{Conclusion}

This paper has attempted to discuss how environmental human rights have been evolved over history. This research has three main conclusions. Firstly, the discussion above shows that environmental awareness about the environmental problems emerged after the 1960s worldwide which in turn triggered the emergence of environmental human rights. The 1960s marked the emergence of environmental thinking in the academic, social and political agenda which greatly impacted the public awareness about environmental issues and marked the beginning of modern environmentalism. All these developments led to the concept that a safe and clean environment is necessary for the safeguarding of human rights at the international level. The discussion on the connection between the environment and human rights emerged in the 1970s on a global scale as a result of the increase of public awareness about environmental problems.

Secondly, the discussion in this paper indicates that environmental human rights are first recognized by environmental law rather than human rights law at the international level. The 1972 Stockholm Declaration is the first document which recognized the linkage between the environment and human rights. It proclaims that the environment is essential for the safeguarding of human rights, which trigged two basic assumptions. Firstly, people have a right to live in a safe environment. Secondly, existing human rights already require safe environment which is called reinterpretation of human rights. Another important environmental law document is the Rio Declaration which recognized procedural environmental rights including the right to access to information, the right to participation in decision making process and the right to access to justice. The first legally binding environmental law document which guarantees procedural rights is the Aarhus Convention. All these three environmental law documents have made a valuable contribution to the development of environmental human rights at the international level.

Thirdly, the discussion above shows that environmental human rights are not guaranteed directly by the International Bill of Human Rights including Universal Declaration of Human Rights, International Covenant on Economic, Social and Cultural Rights and International Covenant on Civil and Political Rights. However, later human rights documents have contributed to the development of environmental human rights significantly. The first legally binding human rights document is the African Charter on Human and Peoples' Rights which guarantees the right to the environment. Similarly, the American Convention on Human Rights and Arab Charter on Human Rights recognize the right to the environment. However, there is no recognition of the right to the environment at the international level. Additionally, no human rights document recognizes reinterpretation of human rights.

\section{References}

ACHPR (1981). African Charter on Human and Peoples' Rights.

Ahmetoğlu, S, Tanık, A. (2020). Management of Carbon Footprint and Determination of GHG Emission Sources in Construction Sector. International Journal of Environment and Geoinformatics, 7(2), 191-204. doi.10.30897/ijegeo.726913.

Anton, D. K., Shelton, D. L. (2011). Environmental Protection and Human Rights. Cambridge University Press.

Atapattu, S. (2002). The Right to a Healthy Life or the Right to Die Polluted? The Emergence of a Human Right to a Healthy Environment Under International 
Law. Tulane Environmental Law Journal, 16, 65126.

Baber, W. F., Bartlett, R. V. (2020). A rights foundation for ecological democracy. Journal of Environmental Policy \& Planning, 22(1), 72-83.

Banisar, D., Parmar, S., de Silva, L., Excell, C. (2011). Moving From Principles to Rights: Rio 2012 and Access to Information, Public Participation, and Justice. Sustainable Development Law \& Policy, 12(3), 8-15.

Bayazıt, M. Önöz, B. (2008) Hydrology of Flood and Drought. Istanbul.

Bayer Altın, T., Barak, B. (2012) Changes and trends in precipitation and air temperature values during the period of 1970-2009 in the Seyhan Basin. Türk Coğ Derg 58, 21-34 (in Turkish).

Berny, N. (2018). Failing to preach by example? The EU and the Aarhus Convention. Environmental Politics, 27(4), 757-762.

Chauhan, A. J., Johnston, S. L. (2003). Air Pollution and Infection in Respiratory Illness. British Medical Bulletin, 68(1), 95-112.

Colombo, U. (2001). The Club Of Rome And Sustainable Development. Futures, 33(1), 7-11.

Cramer, B. W. (2009). The Human Right to Information, the Environment and Information About the Environment: From the Universal Declaration to the Aarhus Convention. Communication Law and Policy, 14(1), 73-103.

Eden, S. (2004). Greenpeace. New Political Economy, 9(4), 595-610.

European Commission (1998). The Aarhus Convention.

Gazioğlu, C. (2018). Biodiversity, Coastal Protection, Promotion and Applicability Investigation of the Ocean Health Index for Turkish Seas, International Journal of Environment and Geoinformatics, 5(3), 353-367. doi. 10.30897/ijegeo.484067.

Gellers, J. (2012). Greening Constitutions with Environmental Rights: Testing the Isomorphism Thesis. Review of Policy Research, 29(4), 523-543.

Gittleman, R. (1981). The African Charter on Human and Peoples' Rights: A Legal Analysis. Virginia Journal of International Law, 22(4), 667-714.

Glazebrook, S. (2009). Human Rights and the Environment. Victoria University of Wellington Law Review, 40(1), 293-350.

Hays, S. P. (1981). The Environmental Movement. Journal of Forest History, 25(4), 219-221.

Humphreys, D. (2015). Know Your Rights: Earth Jurisprudence and Environmental Politics. International Journal of Sustainability Policy and Practice, 10(3-4), 1-14.

Jankuv, J. (2019). Protection of Right to Environment in International Public Law. International and Comparative Law Review, 19(1), 146-171.

Karabıçak, M., Armağan, R. (2004). Çevre Sorunlarının Ortaya Çıkış Süreci, Çevre Yönetiminin Temelleri ve Ekonomik Etkileri. Süleyman Demirel Üniversitesi İktisadi ve İdari Bilimler Fakültesi Dergisi, 9(2),

Koester, V. (2007). The Compliance Committee of the Aarhus Convention-An Overview of Procedures and Jurisprudence. Environmental Policy and Law, 37(2), 83.
Krämer, L. (2018). Citizens rights and administrations' duties in environmental matters: 20 years of the Aarhus Convention. Revista Catalana de Dret Ambiental, 9(1), 1-26.

Kravchenko, S. (2007). The Aarhus Convention and Innovations in Compliance with Multilateral Environmental Agreements. Colorado Journal of International Environmental Law and Policy, 18(1), $1-50$.

Kritidis, P., Florou, H., Eleftheriadis, K., Evangeliou, N., Gini, M., Sotiropoulou, M., ... Vratolis, S. (2012). Radioactive Pollution in Athens, Greece due to the Fukushima Nuclear Accident. Journal of Environmental Radioactivity, 114, 100-104.

Mason, M. (2010). Information Disclosure and Environmental Rights: The Aarhus Convention. Global Environmental Politics, 10(3), 10-31.

Morgera, E. (2005). An update on the Aarhus Convention and Its Continued Global Relevance. Review of European Community \& International Environmental Law, 14(2), 138-147.

Olawuyi, D. S. (2014). Recognizing the Intersections between Human Rights and the Environment in Legal Education and Training. Asian Journal of Legal Education, 1(2), 103-113.

Olmos Giupponi, B. (2019). Fostering environmental democracy in Latin America and the Caribbean: an analysis of the Regional Agreement on Environmental Access Rights. Review of European, Comparative \& International Environmental Law, 28(2), 136-151.

Our World in Data (2019). Future Population Growth.

Pathak, Puneet (2014). Human Rights Approach to Environmental Protection. OIDA International Journal of Sustainable Development, 7(1), 17-24.

Peters, B. (2018). Unpacking the diversity of procedural environmental rights: the European Convention on Human Rights and the Aarhus Convention. Journal of Environmental Law, 30(1), 1-27.

Porras, I. M. (1992). The Rio Declaration: A New Basis for International Co- operation. Review of European Community \& International Environmental Law, 1(3), 245-253.

Samvel, G. (2020). Non-Judicial, Advisory, Yet Impactful? The Aarhus Convention Compliance Committee as a Gateway to Environmental Justice. Transnational Environmental Law, 9(2), 211-238.

Samvel, G. (2020). Non-Judicial, Advisory, Yet Impactful? The Aarhus Convention Compliance Committee as a Gateway to Environmental Justice. Transnational Environmental Law, 9(2), 211-238.

Sands, P. (1993). Enforcing Environmental Security: The Challenges of Compliance with International Obligations. Journal of International Affairs, 46(2), 367-390.

Toth, B. (2010). Public Participation and Democracy in Practice-Aarhus Convention Principles as Democratic Institution Building in the Developing World. Journal Of Land Resources \& Environmental Law, 30 (2), 295-330.

Umozurike, U. O. (1983). The African Charter on Human and Peoples' Rights. The American Journal of International Law, 77(4), 902-912. 
UN (1972, July 25). Report of the United Nations Conference on the Human Environment.

UN (1992, August 12). Report of The United Nations Conference On Environment And Development.

UN (2011, December). Review of Implementation of the Rio Principles.

UN (n.d). The Universal Declaration of Human Rights.

UNECE (2005). Aarhus Convention: Parties to the Aarhus Convention and their dates of ratification. Accessed online:

UNECE (2011, October 29). Environmental Rights Not A Luxury: Aarhus Convention enters into force.

UNECE (n.d). Compliance Committee.

University of Minnesota Human Rights Library (1994). Draft Principles On Human Rights And The Environment, E/CN.4/Sub.2/1994/9, Annex I (1994).

Urbinato, D. (1994). London's historic" peasoupers."(smog in London, England). EPA Journal, 20(1-2), 44-45.

Ülker, D., Ergüven, O., Gazioğlu, C. (2018). Socioeconomic impacts in a Changing Climate: Case Study Syria. International Journal of Environment and Geoinformatics, 5(1), 84-93.doi. 10.30897/ijegeo.406273.

Ülker, D., Bayırhan, İ., Mersin, K., Gazioğlu, C. (2020). A comparative $\mathrm{CO} 2$ emissions analysis and mitigation strategies of short-sea shipping and road transport in the Marmara Region, Carbon Management, 11(6): doi.10.1080/ 17583004. 2020.1852853.

Wates, J. (2005). The Aarhus Convention: a Driving Force for Environmental Democracy. Journal for European Environmental \& Planning Law, 2(1), 211.

Wirth, D. A.(1995). The Rio Declaration on Environment and Development: Two Steps Forward and One Back, or Vice Versa. Georgia Law Review, 29(3), 599-653.

Wisadha, M. A. A., Widyaningsih, G. A. (2018). Human Rights and the Environmental Protection: The Naïveté in Environmental Culture. Udayana Journal of Law and Culture, 2 (1), 73-96. 